\title{
Man Against Volcano: The Eruption on Heimaey, Vestmannaeyjar, Iceland
}

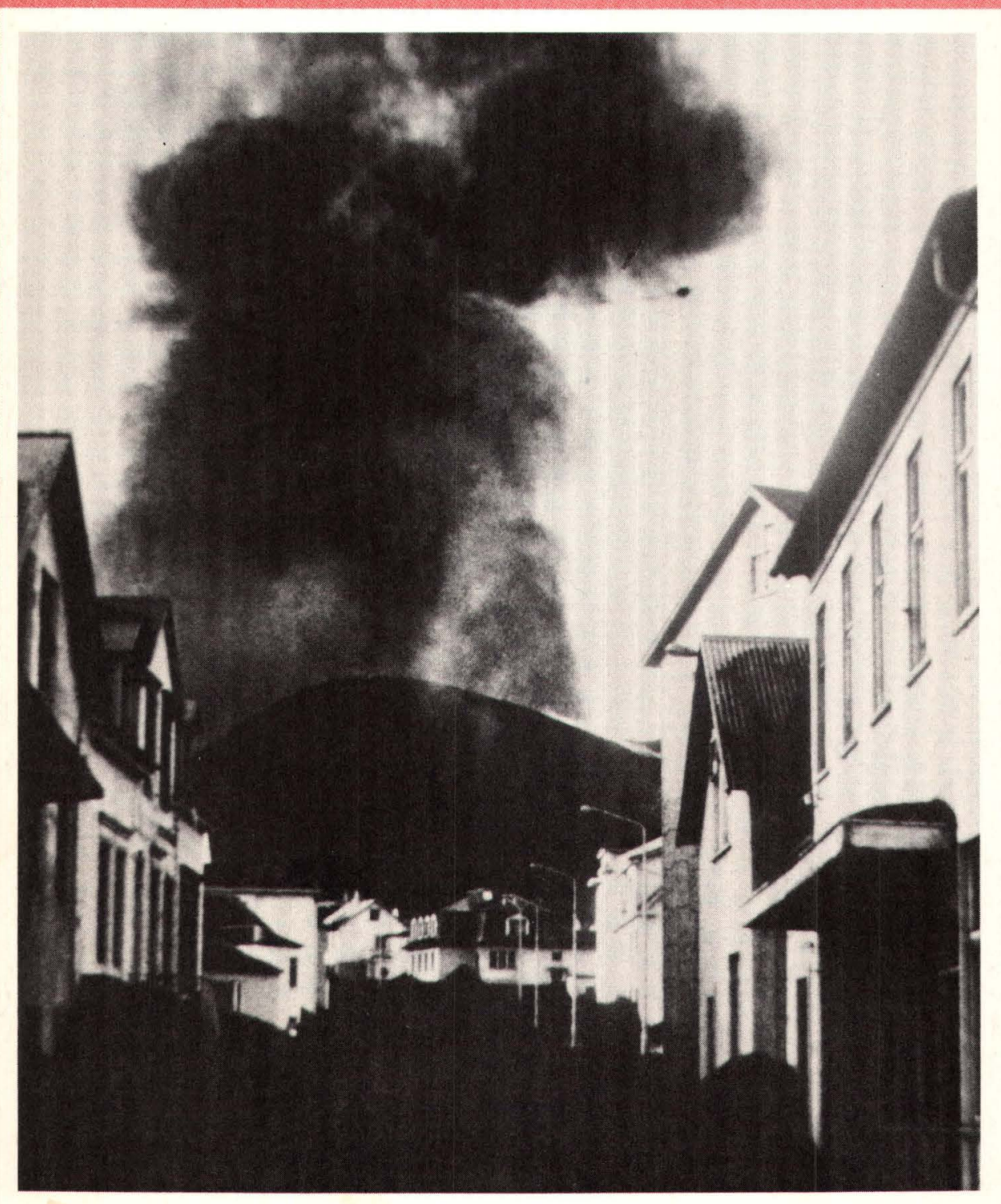


Cover photograph: View looking south east along streets covered by tephra (volcanic ash) in Vestmannaeyjar: Eldfell volcano (in background) is erupting tephra and fountaining lava.

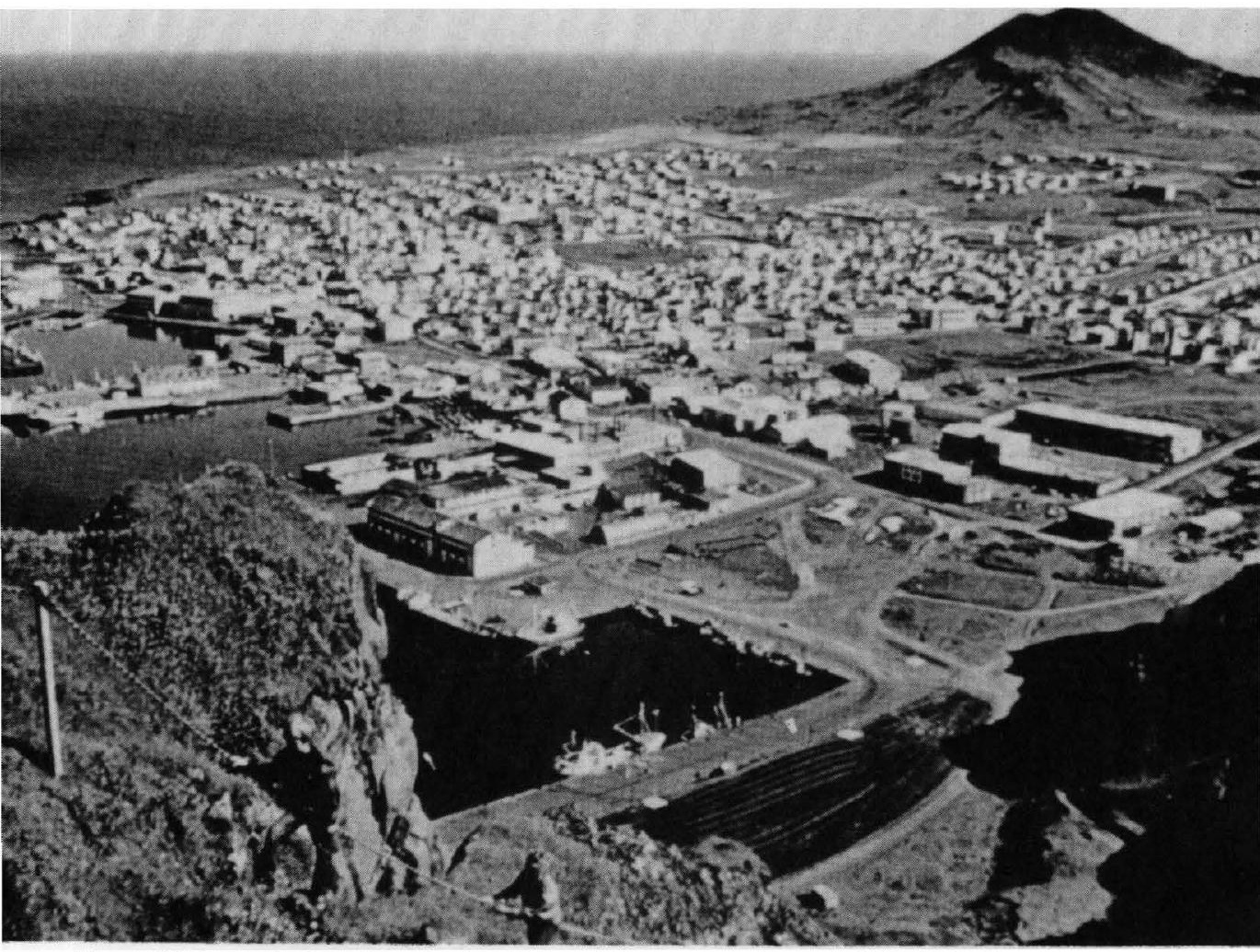

View of Heimaey before the eruption: Town of Vestmannaeyjar with Helgafell in the right background (photo courtesy of Sólarfilma). 


\section{Preface}

The U.S. Geological Survey carries out scientific studies in the geological, hydrological, and cartographic sciences generally within the 50 States and its territories or trusteeships, but also in cooperation with scientific organizations in many foreign countries for the investigation of unusual earth sciences phenomena throughout the world. In 1983, the U.S. Geological Survey had 57 active scientific exchange agreements with 24 foreign countries, and 47 scientific exchange agreements were pending with 30 foreign countries.

The following material discusses the impact of the 1973 volcanic eruption of Eldfell on the fishing port of Vestmannaeyjar on the island of Heimaey, Vestmannaeyjar, Iceland. Before the eruption was over, approximately one-third of the town of Vestmannaeyjer had been obliterated, but, more importantly, the potential damage probably was reduced by the spraying of seawater onto the advancing lava flows, causing them to be slowed, stopped, or diverted from the undamaged portion of the town.

The Survey was interested in the course of the Heimaey eruption because of the possibility that the procedures used to control flowing lava and to reduce the damage to a modern town may some day be useful in Hawaii and possibly even in the continental United States.

This publication is based on observations by the authors, both with the U.S. Geological Survey, as well as on information from the Icelandic Ministry for Foreign Affairs, Icelandic scientists' reports through the Center for Short-Lived Phenomena, other published scientific reports, and articles in popular publications. A number of Icelandic scientists studied the scientific aspects of the eruption. The engineering aspects of the control of lava flows were studied particularly by Prófessors Thorbjörn Sigurgeirsson and Thorleifur Einarsson of the University of Iceland's Science Institute. Also, during 1973, and in subsequent years, Icelandic officials provided support to the authors for this and other volcanological studies. In 1982, the U.S. Geological Survey and the National Research Council of Iceland signed a formal agreement (MOU-IC-1) for the exchange of scientific information in the geosciences, to facilitate exchange of scientific personnel, and to provide a mechanism for cooperation on scientific subjects of mutual interest, such as volcanology, seismology, geothermal studies, glaciology, and remote sensing. 


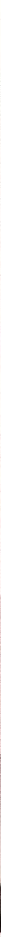

\section{Introduction}

One of the most destructive volcanic eruptions in the history of Iceland began in the early morning of January 23,1973 , near the Nation's premier fishing port, the town of Vestmannaeyjar (Véstmun-ayar), on Heimaey (Háme-aay), the only inhabited isle in the Vestmannaeyjar volcanic archipelago.

Both the fishing port and the group of volcanic islands have the same name-Vestmannaeyjar. In English, Vestmannaeyjar means Westmans' Islands. In Viking times, the Nordic peoples referred to the Irish and other Celtic men as "West" men. Tradition says that the group of volcanic islands, which includes Heimaey and Surtsey, got their name Vestmannaeyjar from escaped Irish (or Celtic) thralls who fled there after killing Hjörleifur Hródmarsson, sworn brother of Ingólfur Arnarson, the first person to permanently settle in Iceland.

The effusive January 23, 1973, eruption was the fifth in a sequence of 16 volcanic eruptions which have occurred in Iceland during the past 36 years. Between 1973 and mid-1983, for example, there have been 11 additional eruptions in Iceland, including 4 in 1980, 3 in 1981 , and 1 in 1983. Two eruptions have occurred at Hekla in 1980 and $1981 ; 8$ eruptions have taken place in the Krafla area of northern Iceland, where an active rifting episode (active spreading apart of the Earth's crust along the midocean boundary between two crustal plates) began in late 1975 and still continues; and, in late 
May 1983 , a subglacial eruption began in the southwestern part of the Grimsvötn caldera which is situated in the western part of Vatnajökull, Iceland's largest glacier. The 1973 eruption on Heimaey was also the second major eruption (the other being Surtsey) definitely known to have occurred in Vestmannaeyjar since the settlement of Iceland in the ninth century, although there is evidence of a submarine eruption in the archi- pelago in September 1896. At least 13 offshore (14 including Heimaey) and approximately 125 onshore eruptions have been documented since Iceland's settlement in about A.D. 874. Ten of the 13 offshore eruptions occurred along the submarine Reykjanes Ridge, an extension of the Reykjanes peninsula. This Ridge lies along a parallel fracture system approximately 110 miles west of the northeast-southwest-trending Vestmannaeyjar.

Oblique aerial view looking north-northwestwards of the island of Heimaey, Vestmannaeyjar, Iceland, in August 1966 , showing the fishing town of Vestmannaeyjar, the east-west-trending harbor in the background, and the extinct volcano Helgafell rising to $741 \mathrm{ft}$ in the right center of the island. On January 23, 1973, lava began to pour from a 0.9-mi north-northwest-trending fissure to the east (right) of Helgafell. Eldfell eventually grew to be similar in height to Helgafell, $0.6 \mathrm{mi}$ to the northeast.

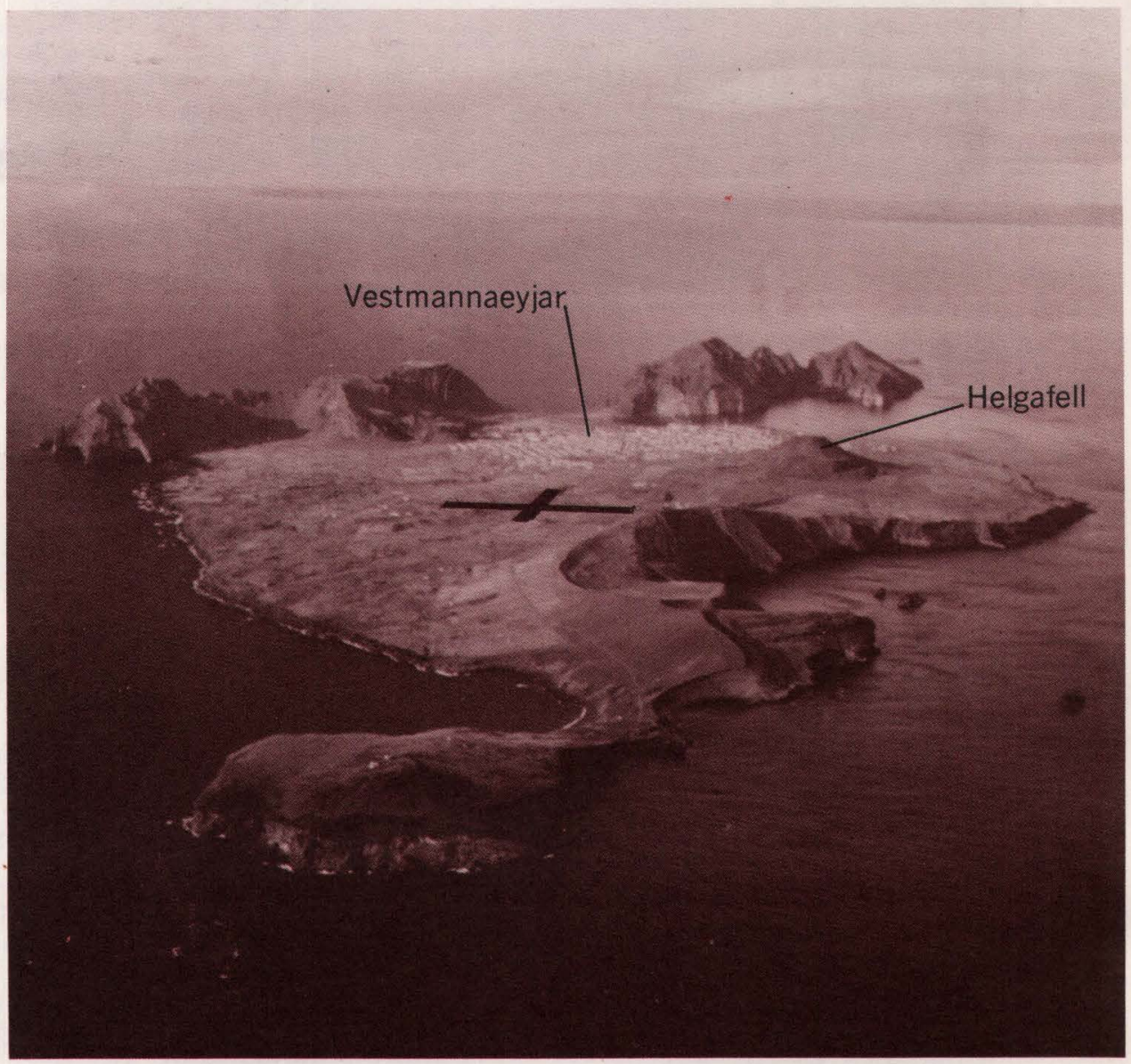




\section{Volcanic Eruptions in Iceland During the 36-Year Period: 1947-1983}

Date of Start
of Eruption

Geographic

March 29, 1947

Location

October 26, 1961

November 14, 1963

Hekla

Askja

Surtsey (Vestmannaeyjar)

May 5, 1970

Hekla

January 23, 1973

Heimaey (Vestmannaeyjar)

December 20, 1975

Krafla

April 27, 1977

September 8, 1977

March 16, 1980

July 10,1980

August 17, 1980

October 25, 1980

January 30,1981

April 9, 1981

November 18, 1981

May 19,1983

Grímsvötn (Vatnajökull)

Except for the main island of Heimaey, all the islets in the archipelago are composed of Holocene (geologically recent; that is, less than 10,000 years old) basalts, and, except for Surtsey, the islets are bounded by high sea cliffs and extend out of the sea as a series of stacks. Surtsey has a sandy point to the north and a narrow boulder and cobble beach fringing the rest of the island, including the steep lava cliffs on its windward side and indurated (hard and compacted) tuff on the west. Rocks of Pleistocene age (the span of geologic time from about 3 million to 10,000 years ago) crop out on the north and south parts of the island of Heimaey. These are overlain by younger Holocene basalt flows capped by a prominent volcano, Helgafell, which last erupted 5,000 years ago.

The Vestmannaeyjar islands parallel the structural trend of tectonic fissures (gjár), grabens, and crater rows on the mainland to the north in the eastern volcanic zone.

This is a zone of historically active volcanoes, including Hekla, Katla, and the famous Laki fissure eruption of 1783.

The Laki eruption derives its name from a mountain (Laki) which was split by a fissure from which a large volume of lava and gas emanated. In Iceland, the eruption is referred to as Skaftáreldar; the crater row which formed along the fissure is called Lakagigar, and the multiple lava flows are collectively known as Skaftáreldahraun.

The Laki eruption produced the largest lava flow on Earth observed in historic times, 2.9 cubic miles of lava which inundated 218 square miles. According to Prófessor Sigurgeirsson, the Reverend Jón Steingrímsson, an Icelandic minister who observed the Laki eruption, was probably the first to describe the effect of water on the flow of lava. During 1983, in commemoration of the 200th anniversary of this awesome eruption, a new map of Skaftáreldahraun and several books will be published by Icelandic scientists, including a historical review of Skaftáreldar by. the late Prófessor Sigurdur Thorarinsson, one of his last research efforts completed just prior to his unexpected death on February 9 , 1983 , at the age of 71 . 


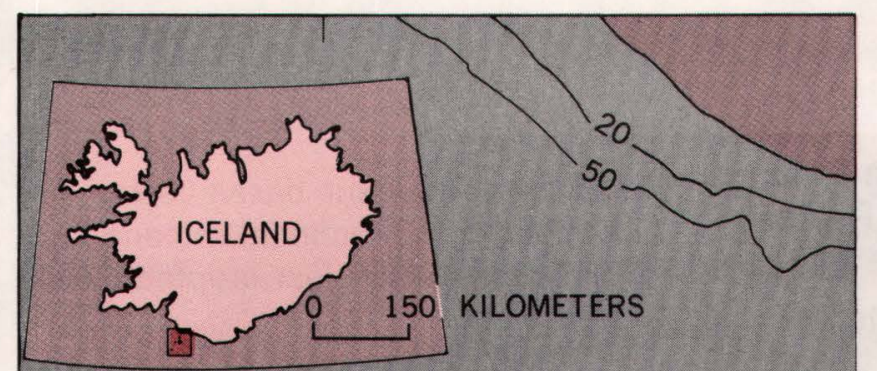

Left-Index map of Vestmannaeyjar (modified from Thorarinsson, 1964, and Iceland Geodetic Survey).

Vestmannaeyjar
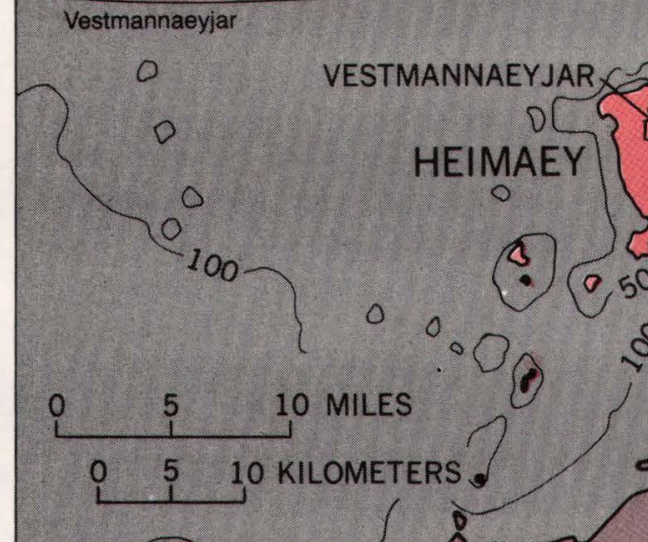

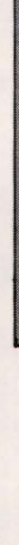
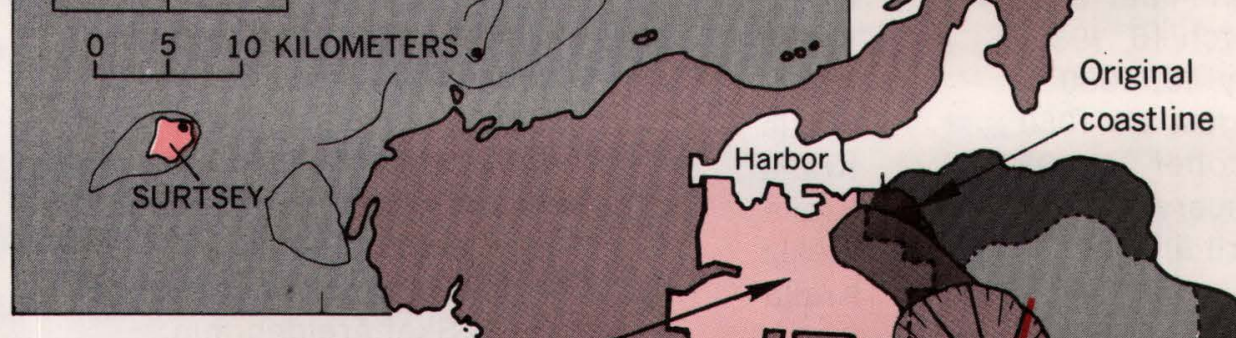

VESTMANNAEYJAR

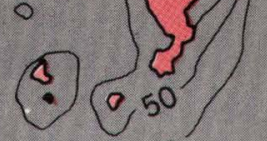

T2 0 


\section{Course of the Eruption}

The 1973 eruption began just before 2 a.m., January 23, on the eastern side of Heimaey, approximately 1,100 yards from the center of town. A north-northeast-trending fissure rapidly opened to a length of about $1 \frac{1}{4}$ miles, traversing the island from one shore to the other. Spectacular continuous lava fountains (curtain of fire) played in the initial phase of the eruption, but the activity soon consolidated to a small area along the fissure about one-half mile northeast of Helgafell. Also during the first 3 days, submarine volcanic activity occurred just offshore at the north and south ends of the fissure vent. Within 2 days a cinder-spatter cone rose more than 110 yards above

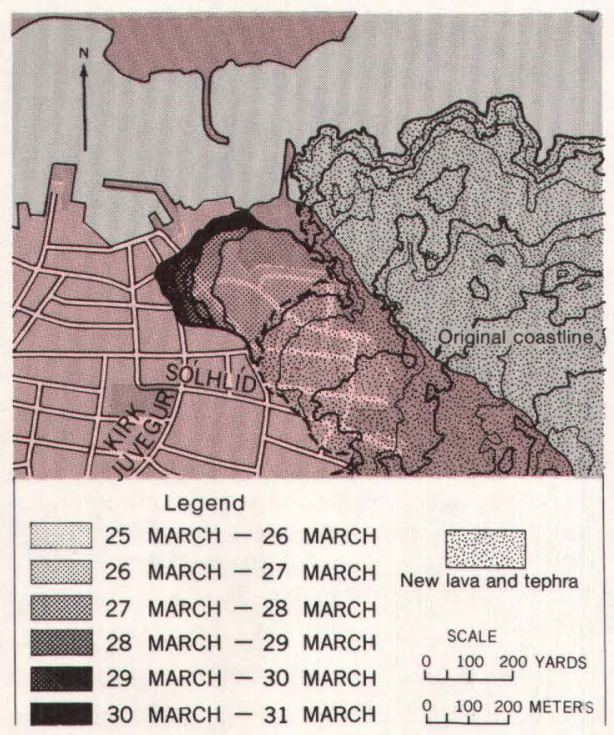

Daily movement of lava into Vestmannaeyjar in late March 1973. Cooling operations finally halted the flow against the fish-processing plants shown on pages 12 and 13. Light lines show former roads of the town under the lava field (modified from Jónsson and Matthíasson, 1974). sea level and was later named Eldfell or "fire mountain" by the official Icelandic place name committee. The output of lava and tephra (a collective term for fragmental volcanic materials initially airborne, such as ash and bombs) was estimated to be about 130 cubic yards per second. Within a few days after the eruption, strong easterly winds resulted in a major fall of tephra on the town of Vestmannaeyjar, completely burying homes close to Eldfell. By early February the tephra fall slackened markedly, but a massive lava flow approached the eastern edge of the town and threatened to fill in the harbor of Iceland's most important fishing port. Also in early February submarine activity just

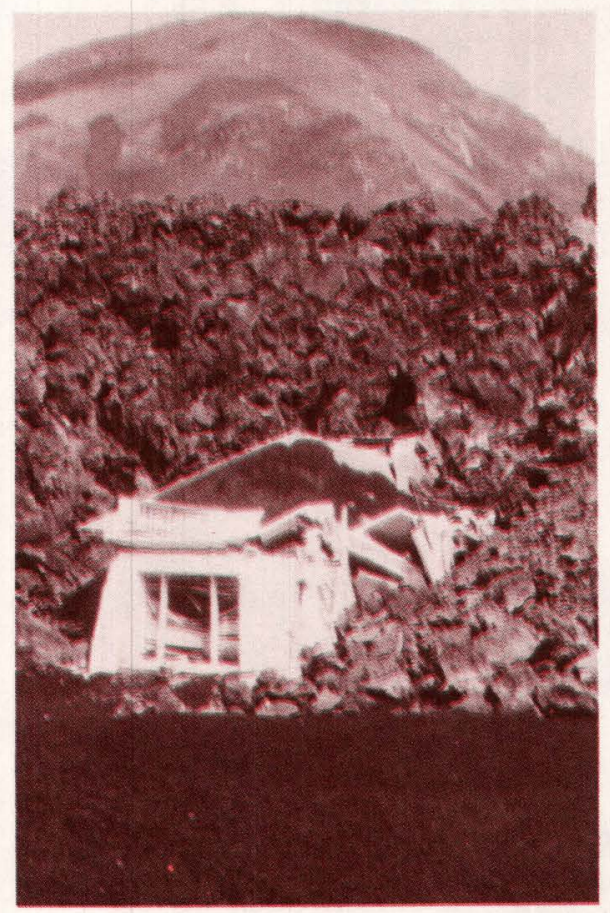

View on July 23, 1973, looking north toward a house engulfed by the March lava flow on the easteri: part of Vestmannaeyjar. 
north of the fissure severed an electric power cable and a water pipeline which supplied electrical power and water from the Icelandic mainland.

Icelandic geologists and geophysicists monitored the volcano continuously, both from the air and the ground. Frequent aerial photographs were taken by the Iceland Geodetic Survey. Foreign scientists also made short-term observations. Satellite studies and imagery of the eruption were acquired by both the NOAA-2 and the Landsat-1 satellites. Posteruption aerial photographic and thermographic surveys were carried out under a cooperative study by the U.S. Geological Survey and the University of Iceland Science Institute in association with the Icelandic National Research Council.

By the end of February the cinder-spatter cone was more than 200 yards high. The central crater of Eldfell fed a massive blocky (aa lava) flow which moved slowly but relentlessly toward the north, northeast, and east. By early May this flow was 10 to 23 yards high at its front, averaged more than 40 yards thick, and was as much as 110 yards thick in places. Its upper surface was littered with scoria (cinderlike fragments of dark cellular lava) and volcanic bombs, as well as large blocks from the main cone which broke off and were carried along with the flow. The largest block soon was dubbed "Flakkarinn" (The Wanderer). Some of these blocks of welded scoria were about 200 yards square and stood 20 yards above the general lava surface and were rafted more than 1,000 yards. Measurements made from a series of aerial photographs taken from the end of March to the end of April indicated that the lava was flowing as a unit about 1,000 yards long by 1,000 yards wide with an average speed of 3 to 9 yards per day.

As the flow advanced to the north and east, large blocks slumped from the cone on February 19 and 20 and moved toward the southeastern part of town. Also, in late March a second large lava flow moved northwest on the west side of the main flow and covered many houses and the town powerplant.

By February 8, lava ejection dropped from about 130 cubic yards per second to 80 cubic yards per second; by the middle of March to 13 cubic yards per second; and by the middle of April to about 7 cubic yards per second. As noted before, easterly winds blew tephra over the town during the early stages of the eruption. By January 29, the thickness of tephra varied from less than 1 yard in the

\begin{abstract}
(Top right.)
Eruption of Eldfell volcano as viewed from the NOAA-2 weather satellite, 33 hours after the eruption began. The plume extends $37 \mathrm{mi}$ downwind to the east, away from the town of Vestmannaeyjar. This thermal infrared image also shows the "hot" area of lava flows at the base of the plume (National Environmental Satellite Data and Information Service, NOAA).
\end{abstract}

\section{(Bottom right.)}

View on July 23, 1973, southeast across homes partially buried by tephra.

Vapor-shrouded Eldfell looms in the distance. Pipes which conveyed seawater to the lava flows cross the tephra in the middle ground Gases rise from the tephra behind the telephone pole. 

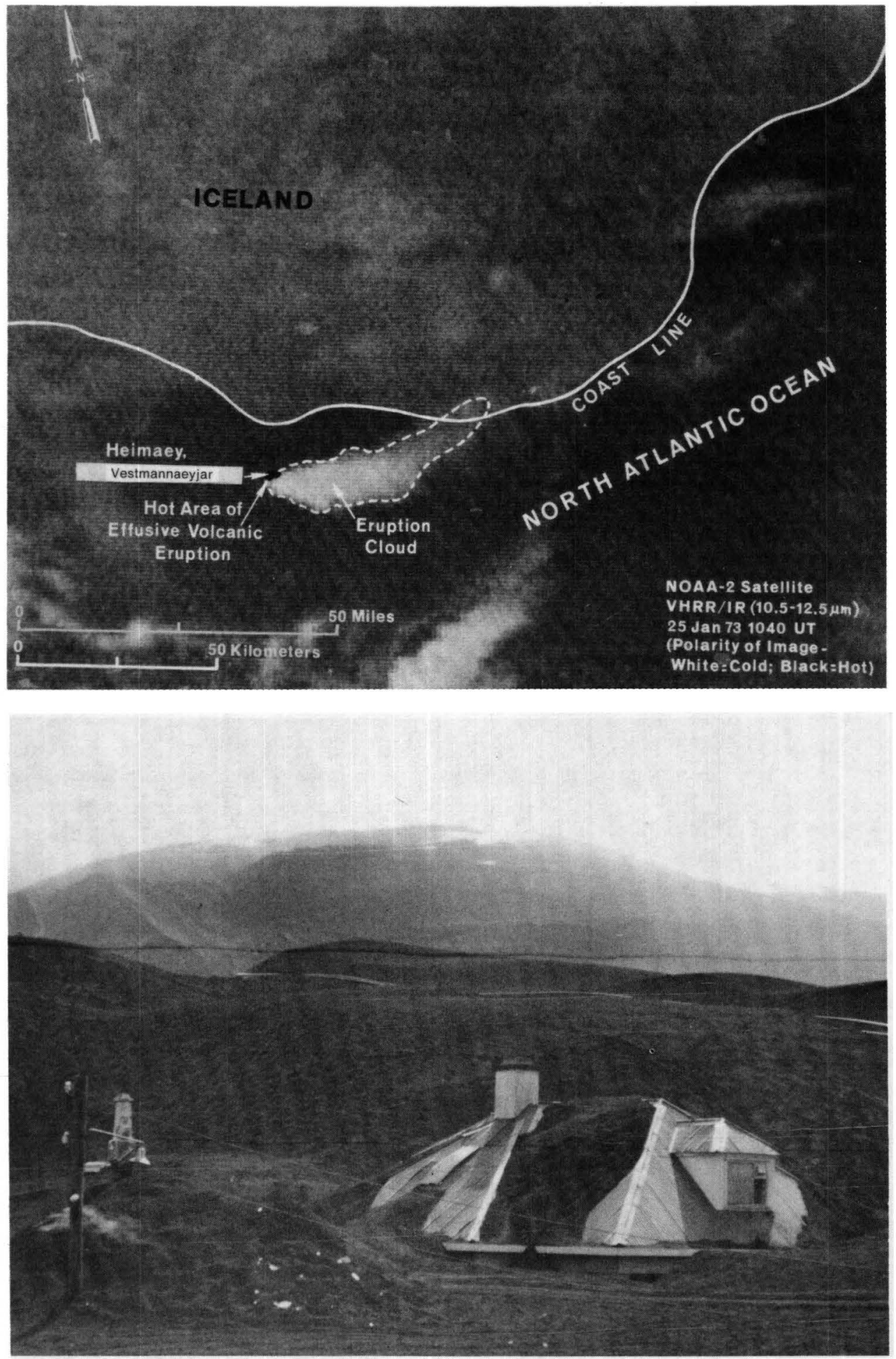
northwest part of town to more than 5 yards in the southeast part.

The eruption stopped in early July 1973; flowing lava was no longer visible, although hidden subsurface flow may have continued for awhile. Earlier, on May 26 , for example, short-lived submarine activity was discovered by a fishing boat captain about 4 miles northeast of Heimaey only 1 mile from the Icelandic mainland. According to preliminary estimates about 300 million cubic yards of lava and 26 million cubic yards of tephra were deposited on and adjacent to Heimaey.

Studies of the volcano's eruptive products by a number of Icelandic scientists have shown that, as the eruption progressed, the composition of the material changed until it became similar in composition to the lava making up the island of Surtsey. This compositional change implies that the lava probably came from a zoned magma chamber enriched in alkalies and silica in its upper part. The chemical changes in the lava were accompanied by mineralogic changes as well as temperature changes. The temperature of the lava also varied from $1,885^{\circ}$ to $1,930^{\circ} \mathrm{F}$ $\left(1,030^{\circ}-1,055^{\circ} \mathrm{C}\right)$ during the first week of the eruption and increased later to as much as $1,975^{\circ} \mathrm{F}$ $\left(1,080^{\circ} \mathrm{C}\right)$.

View on July 23,1973 , north across homes partially buried by tephra in the eastern part of Vestmannaeyjar. The lava flows loom in the background. Gases that are moving through the tephra rise from the house on the right. The houses were eventually exhumed and restored.

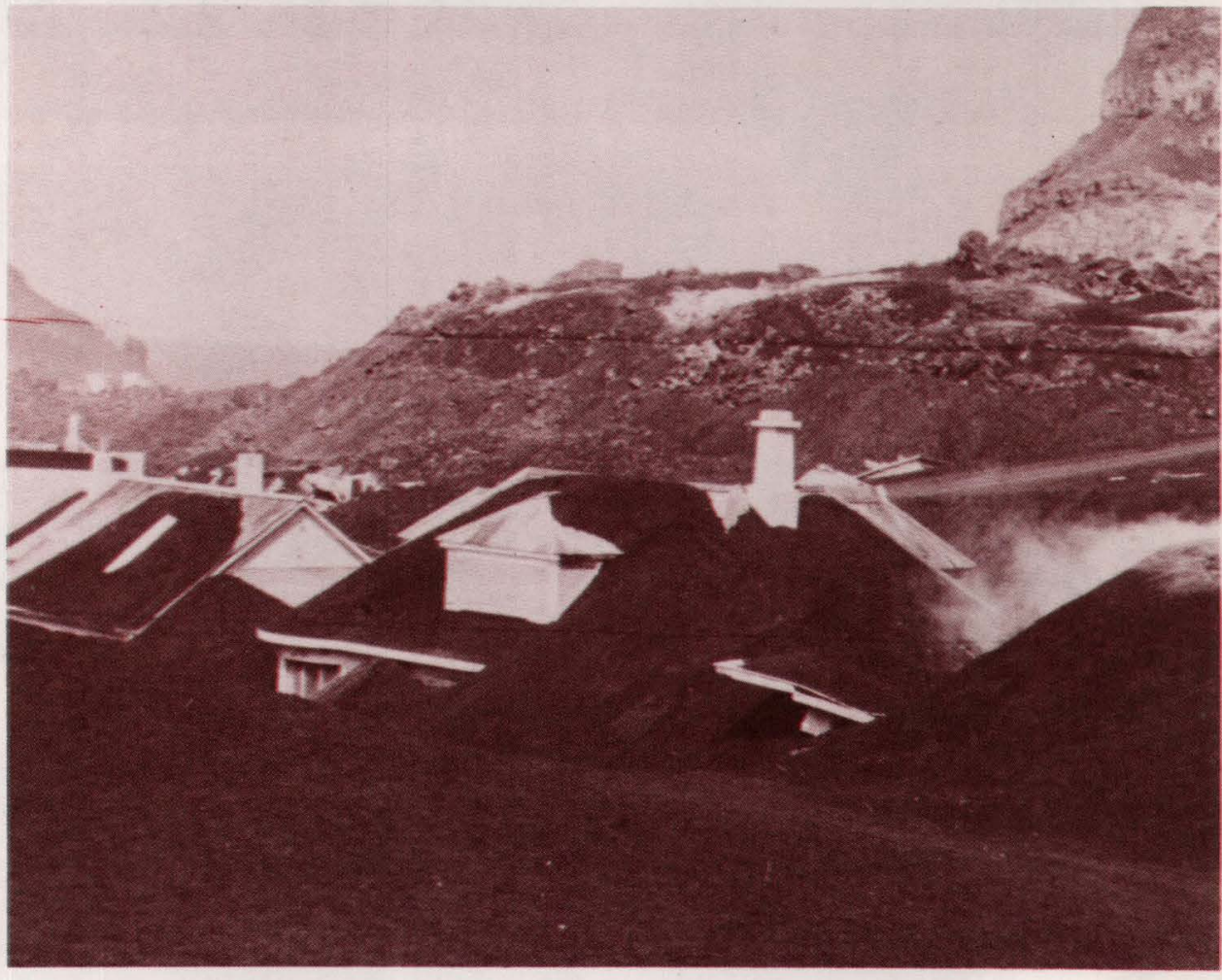


Volcanic gases of widely varying composition were collected from several locations, showing that processes of gas fractionation operate effectively over short distances. Gases collected at sea along the submerged part of the active eruptive fissure were dominantly carbon dioxide. Gases collected at sea bubbling up from cooling submerged lava flows were found to be about 70 percent hydrogen.

Poisonous gas accumulated in low areas within the eastern part of Vestmannaeyjar and particularly was concentrated in houses partially buried by tephra. The gas contained 98 percent carbon dioxide and some carbon monoxide and methane. The gas had a subtle, somewhat sour odor. One fatality resulted from breathing gas within a building, and several other people were partially overcome by the gas.

The origin of the carbon dioxide is a matter of some conjecture among geologists familiar with its occurrence on Heimaey. Perhaps it separated from the other volcanic gases (chiefly water and sulfur dioxide) at the volcano's vent, flowed downhill to the town, and collected in low areas. Carbon dioxide concentrations also have been associated with eruptions from Iceland's best known volcano, Hekla; sheep have been found asphyxiated in small dales.

Another more likely possibility is that the volcanic gas moved up and outward from deeper within the volcanic conduit through older volcanic rocks directly into the town. Other gases were removed through condensation or reaction, and the travel path was such that carbon dioxide remained the dominant residual gas. A sizable tephra wall was constructed by bulldozers between the vent and town to divert the gas; a long trench was also excavated to permit the escape of steam. Neither barrier was completely effective.

\section{Destruction Caused by the Eruption}

The prolonged destruction related to the course of the eruption was twofold: the highly visible destruction of homes, public buildings and installations, commercial properties, and partial infilling of the harbor by tephra falls and lava flows; and the economic and social impact on the residents of Vestmannaeyjar, local commerce, and the national and international economy of Iceland.

Within 6 hours after the eruption began, nearly all of Heimaey's 5,300 residents had been evacuated safely to the mainland. This rapid evacuation was accomplished through the foresight of the Icelandic State Civil Defense Organization, which had a contingency evacuation plan ready for just such a disaster. The fishing fleet in port expedited the evacuation.

Homes and farmsteads close to the rift were soon destroyed by tephra burial or by fire from lava bombs and flows. The heavy tephra fall caused severe property damage a few days after the onset of the eruption. Numerous homes 
were completely buried by tephra, set afire by glowing lava bombs, or overridden by the advancing front of lava flows. Although many structures collapsed from the weight of the tephra, dozens were saved by crews of volunteers who cleared the roofs of accumulated tephra and tacked corrugated iron "shutters" over the windows.

By early February the lava had begun to narrow the harbor entrance, a situation which threatened the future use of Vestmannaeyjar as Iceland's prime fishing port. The harbor on Heimaey is the best along the entire south coast of Iceland and is located in the midst of some of the richest fishing grounds in the North Atlantic.

In late March, a new surge of lava into the eastern edge of the town destroyed a large fish-freezing plant, damaged two others, and destroyed the local powergenerating facility and a great number of homes. By early May, some 300 buildings had been engulfed by lava flows or gutted by fire, and another 60 to 70 homes had been buried completely by tephra.

The economic and social consequences of the eruption will be felt for many years. The initial social impact was in the total upheaval of a 1,000-year-old island community. A proud and industrious people, with many close bonds of family and friendship, had been uprooted involuntarily, and their livelihoods altered in most cases. Short-term and long-term costs totaled many tens of millions of dollars, a very

View on July 23, 1973, southeast from dock area in the northern part of Vestmannaeyjar toward edge of lava flow where it stopped against and between two fish-factory buildings. Two boys can be seen in the right background sweeping up the tephra. By July 1974 the lava had been completely removed and restoration of the factories had begun.

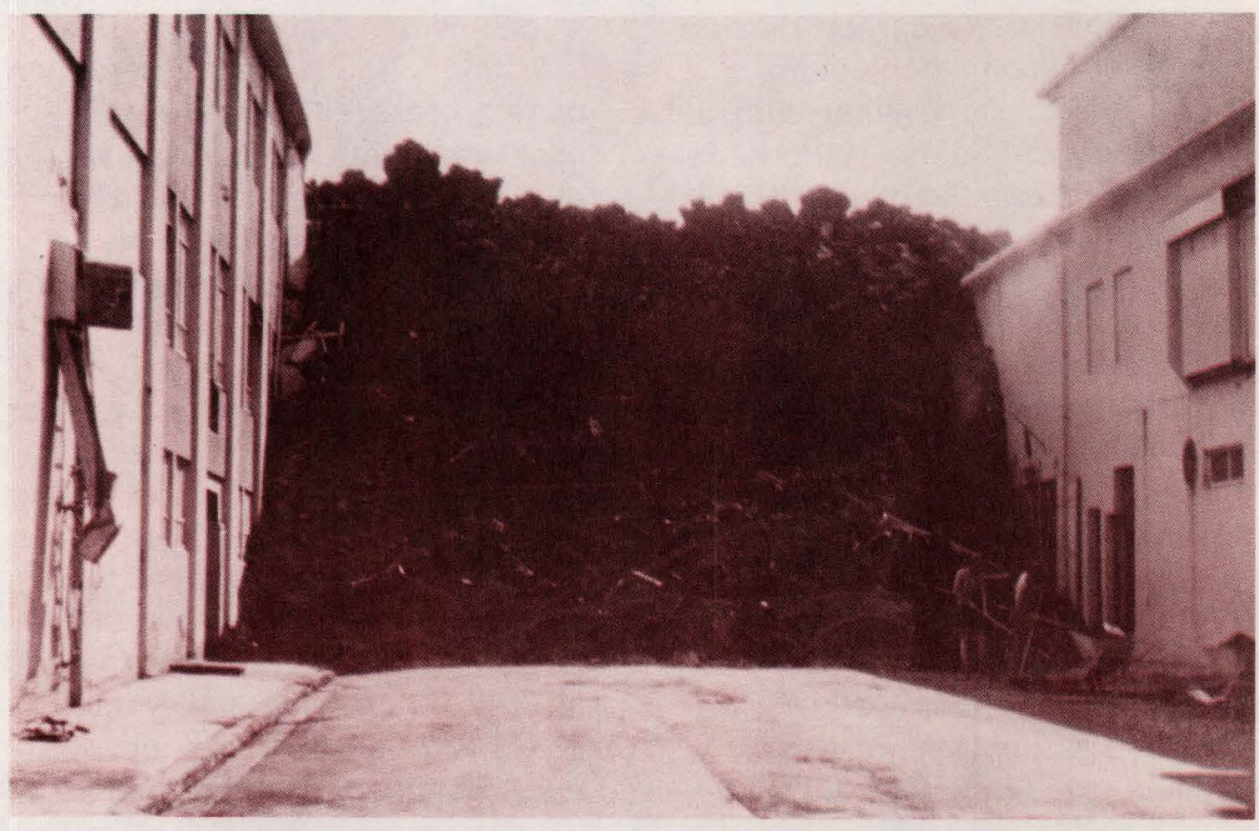


large amount when compared with Iceland's 1971 gross national product (GNP) of $\$ 500$ million. The location and housing and other services for 5,300 people, for example, was equivalent in national impact to finding emergency housing with overnight notice for 5.3 million Americans.

\section{Control of the Lava Flows}

Icelanders, from the time of settlement to the present day, have had to contend with the consequences of natural disasters: volcanic eruptions, glacier outburst floods (jökulhlaups), earthquakes, advances of outlet glaciers, and periods of climatic change (usually caused by the presence of sea ice off the north and east coasts). All Iceland, either directly or indirectly, pitched in to lessen the burden on the residents of Heimaey.

Of great interest was the decision by officials, on the advice of Icelandic geologists and geophysicists, to "fight" the lava flows. Drawing on field observations made on Surtsey, together with theoretical calculations on the cooling effect of water on molten lava, and on small experiments conducted on Surtsey and later on Heimaey at the beginning of the eruption, several Icelandic scientists recommended that cooling and hardening of lava by spraying of seawater be used to try to impede or stop the flow of lava on Heimaey. This effort ultimately became the most ambitious program ever attempted by man to control volcanic activity and to minimize the damage caused by a volcanic eruption. Consequently, it was an experiment of importance to other

View on July 7, 1974, southeast from dock area in the northern part of Vestmannaeyjar after removal of lava flow which had stopped against and between two fish-factorv buildings.

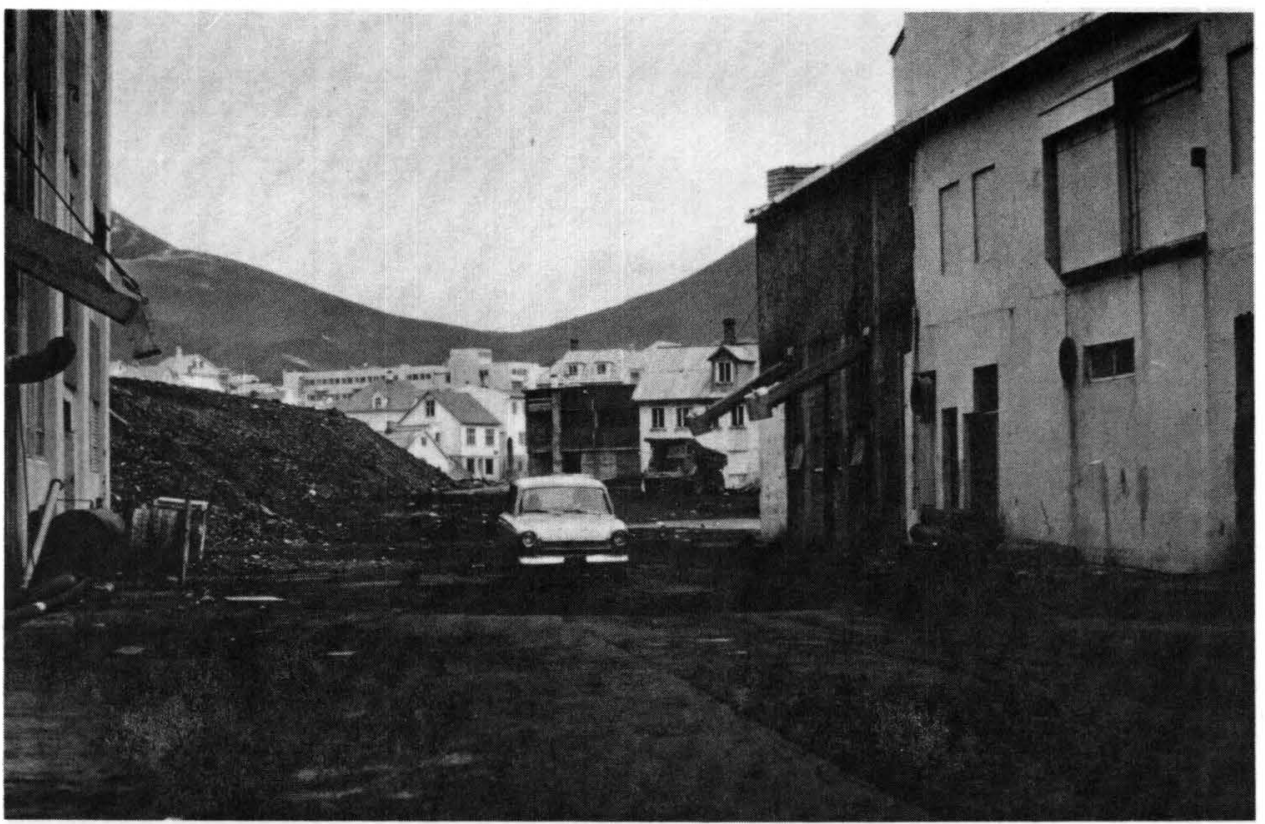




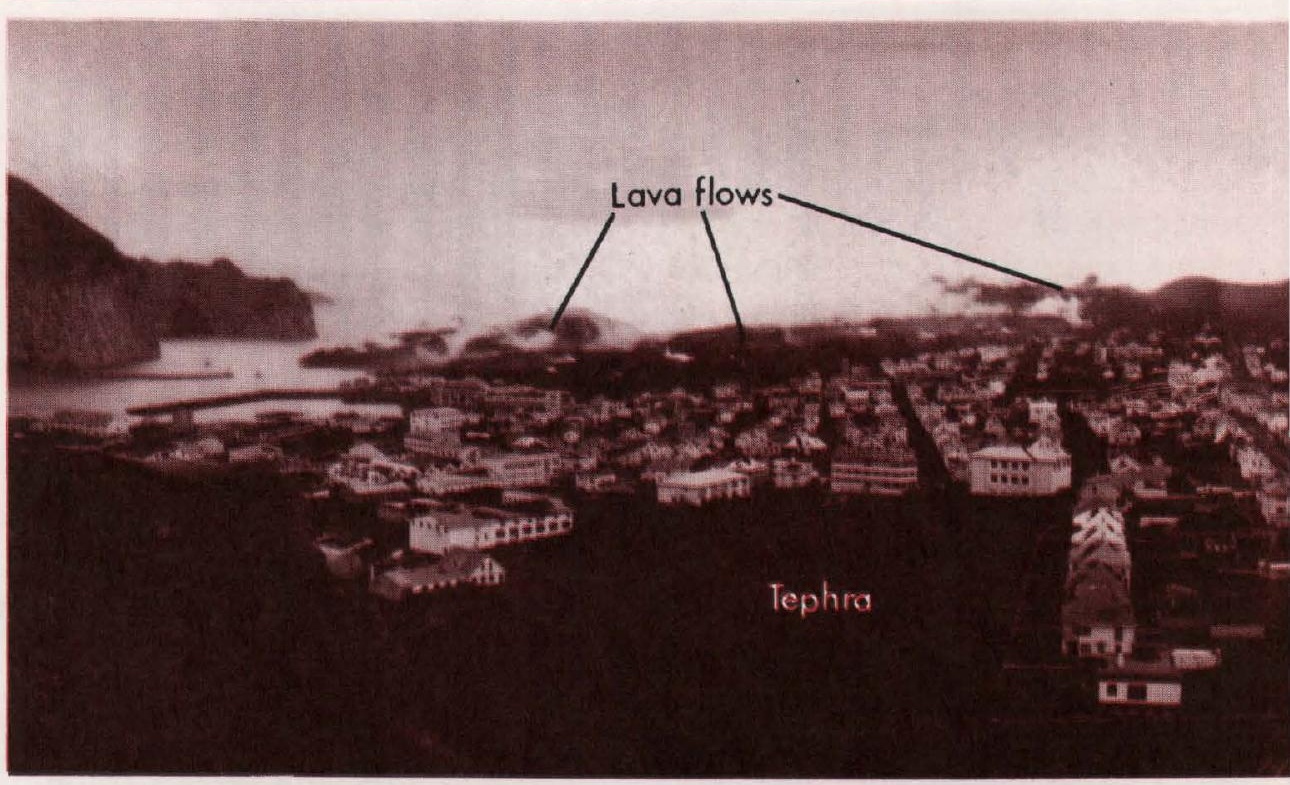

A panoramic view east-southeast across the fishing port of Vestmannaeyjar on May 5, 1973. Dark, tephra-covered ground is apparent, with lava flows into the town and harbor in the left background.

View to the south from Vestmannaeyjar's outer harbor on May 4, 1975. Seawater is being sprayed directly onto the lava flow front to arrest infilling of the harbor entrance.

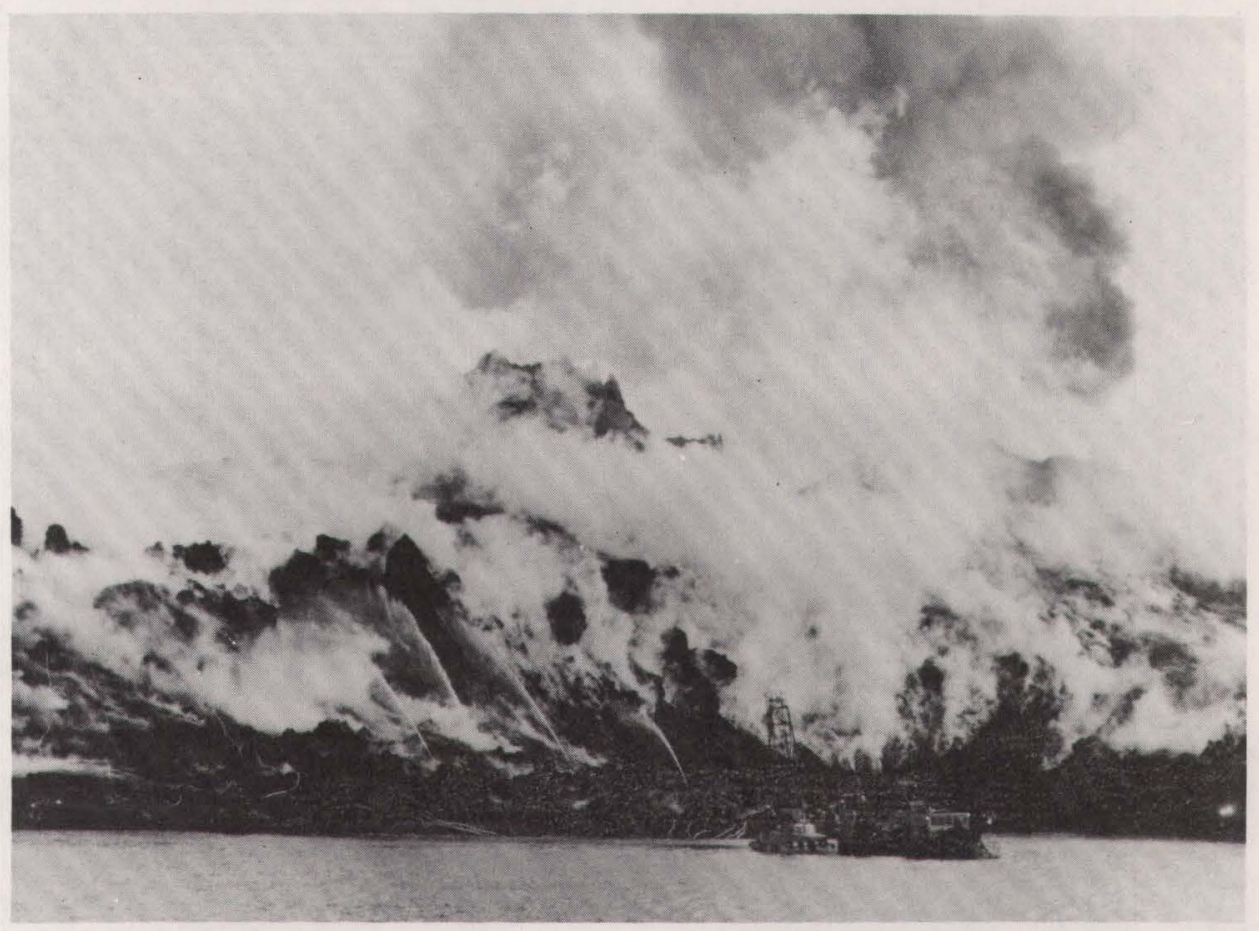




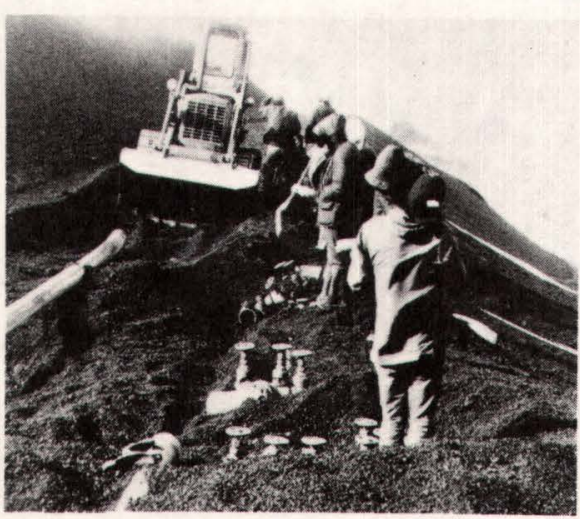

On May 4, 1973, workmen laid additional pipes to carry seawater up onto the lava flow front and tephra bulwark to cool and harden the still-flowing lava behind the chilled lava margin.

Area around eastern Vestmannaeyjar showing the parts of the new lava field that were cooled over different periods of time and the amount of seawater pumped. Heat extraction areas also shown (modified from Jónsson and Matthiasson, 1974). seawater was heated and evaporated. The change in surface texture and color can be noted readily on color aerial photographs.

From February 6, 1973, until the lava cooling operation ended on July 10, 1973, approximately 8 million cubic yards of seawater were pumped onto the lava flows, converting about 5 million cubic yards of molten lava into solid rock. At the peak of the lava cooling, in early April 1973, 75 men were employed around the clock.

Like all volcanic eruptions, the Heimaey eruption was a special case, and the methods employed to control the lava flows were especially suited to local conditions. First, the initial eruptive fissure was

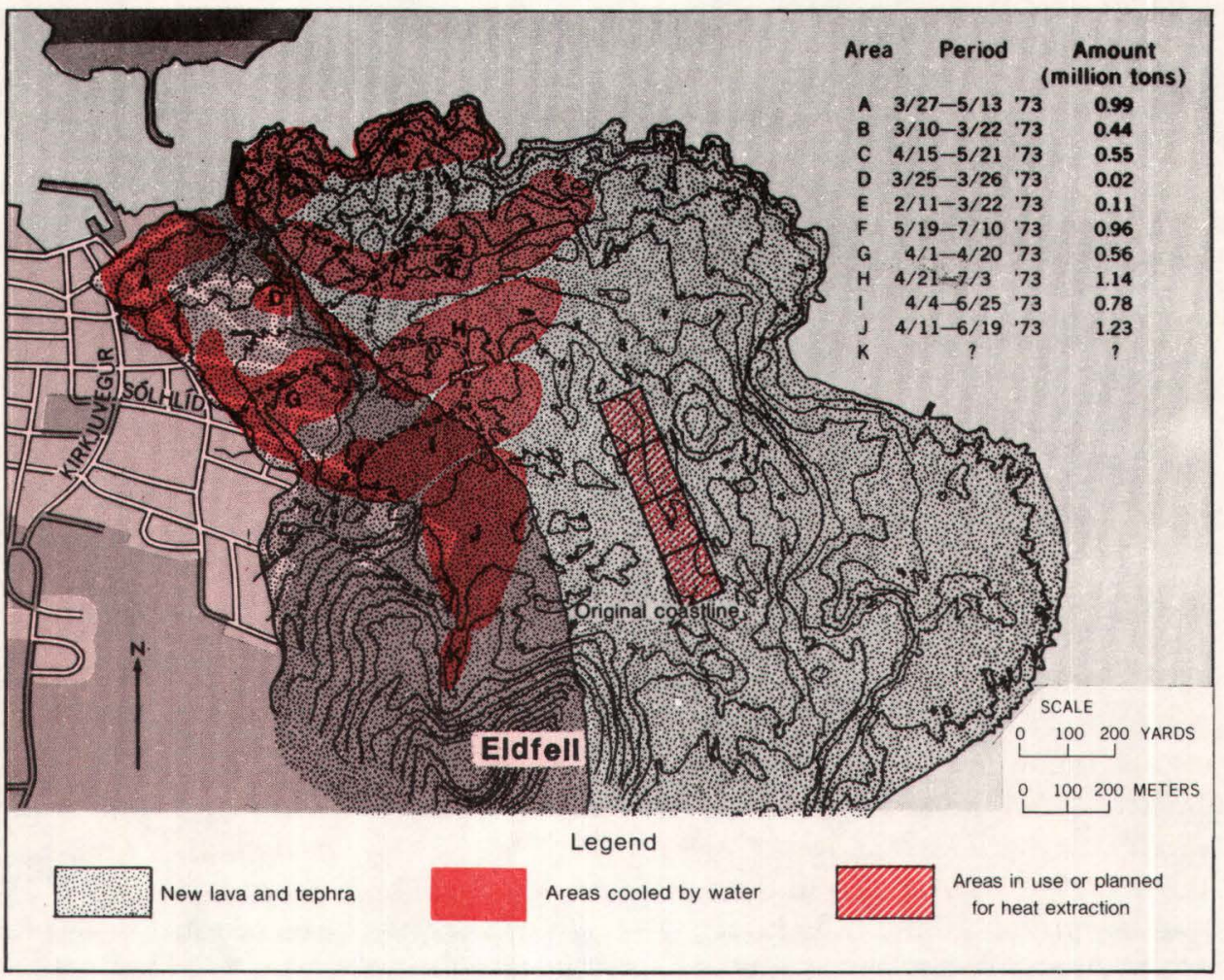




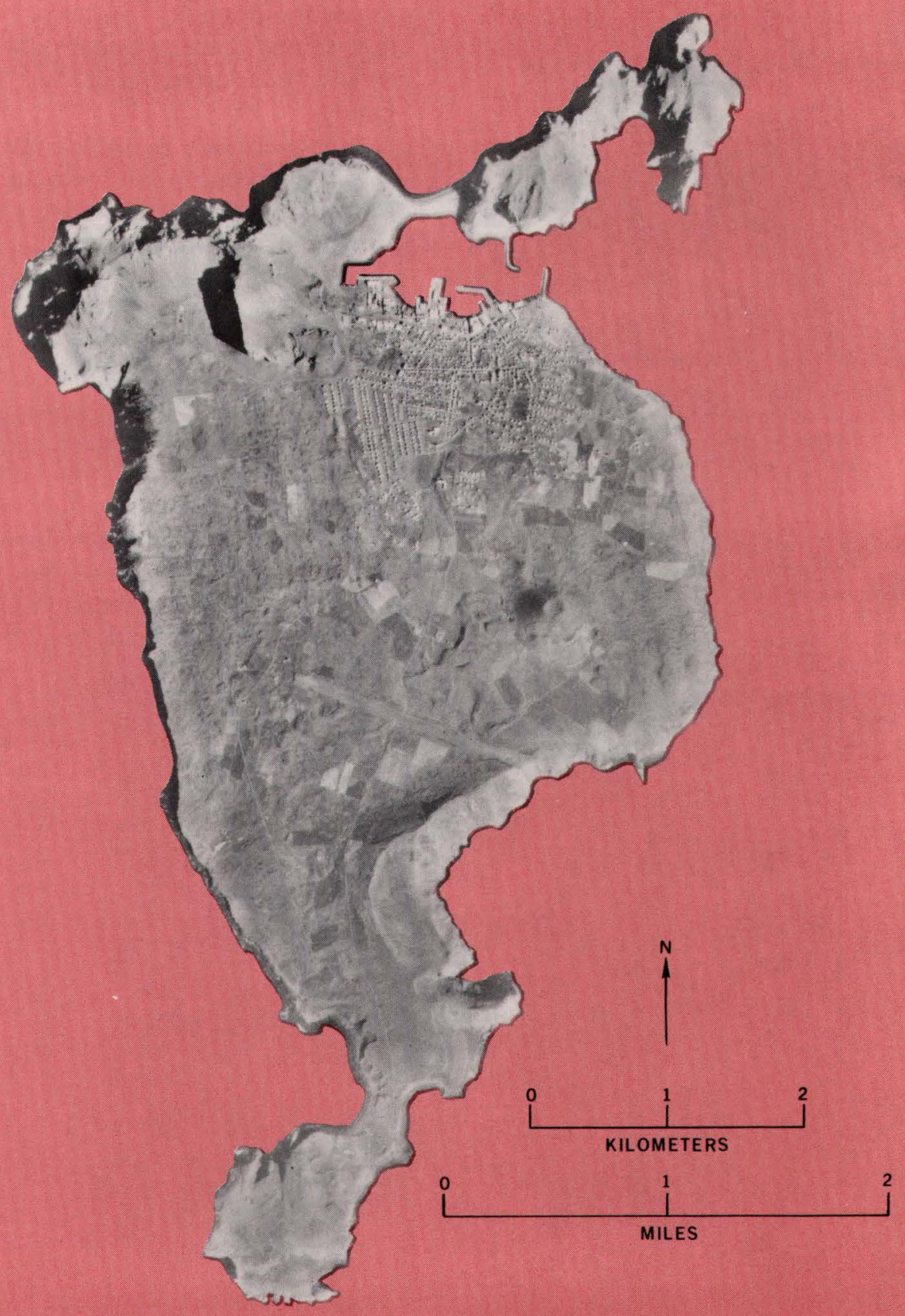

Vertical aerial photograph taken on August 4, 1960, of the island of Heimaey, Vestmannaeyjar, Iceland, showing the fishing port of Vestmannaeyjar, the crater of Helgafell volcano, and the single airstrip. (photo by U.S. Air Force). 


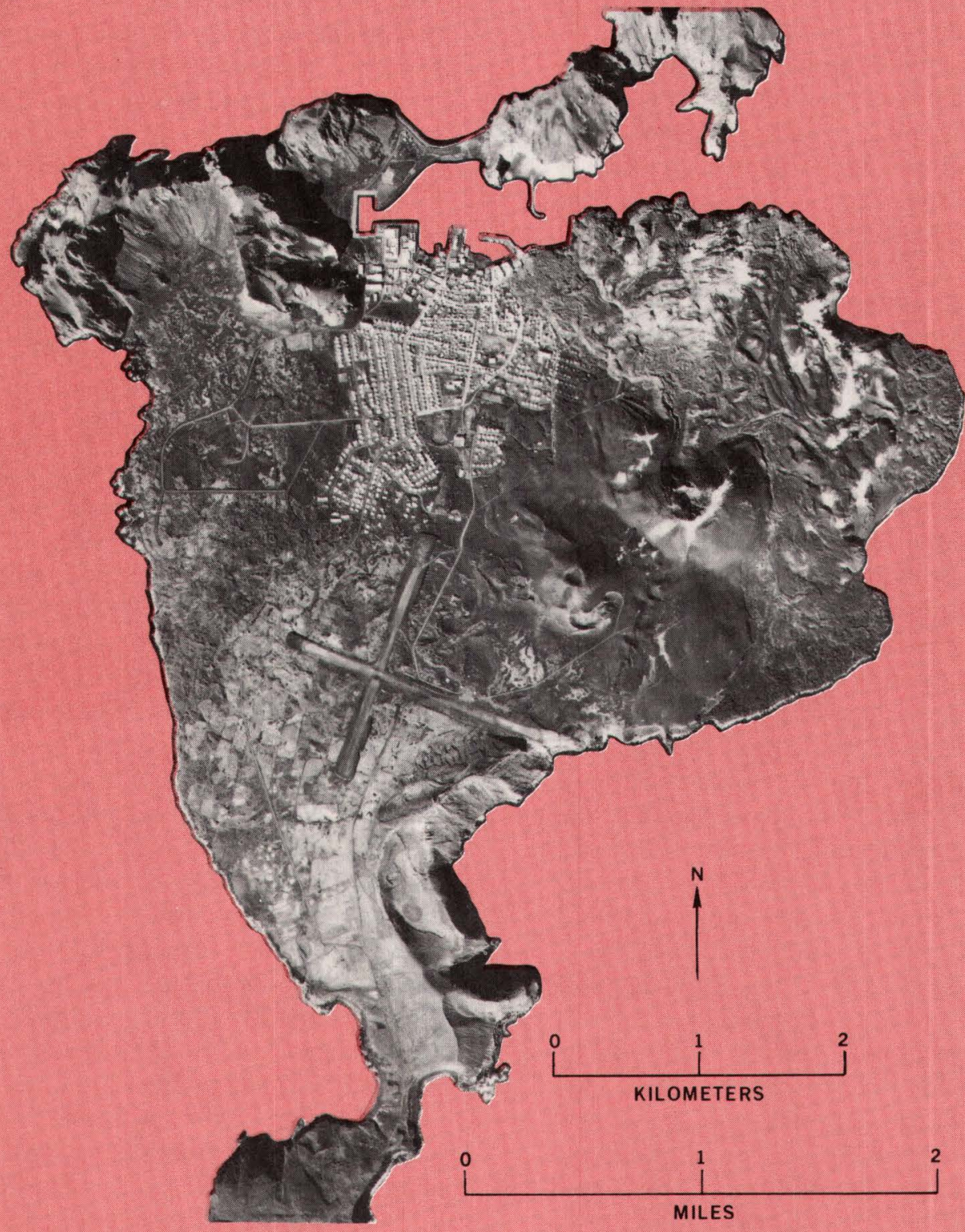

Vertical aerial photograph taken on September 8, 1973, of the island of Heimaey, Vestmannaeyjar, Iceland, showing the fishing port of Vestmannaeyjar, the craters of Helgafell and Eldfell volcanoes, the double airstrip, and the new land on the east (Iceland Geodetic Survey). 
only 1,100 yards from the center of a large town with an adjacent and economically important harbor, and consequently it was in the national interest to attempt to minimize damage. Secondly, the main lava flow was viscous and slow moving, allowing time to plan and carry out the control programs. Thirdly, seawater was readily available in the nearby harbor. And fourthly, transport by sea as well as by a local road system was good, and it was relatively easy to move in pumps, pipe, and heavy construction equipment. Nevertheless, it is likely that some of the lessons learned from the Heimaey experience can be adapted to eruptions in other places.

Scientists and planning authorities also had the benefit at Heimaey of detailed topographic maps rapidly produced from vertical aerial photographs. These maps, in connection with geodetic surveys, permitted measurement of the rate of movement of the main lava flow and an assessment of the best places to build lava diversion barriers. They also were critical in planning for administrative, engineering, and scientific purposes.

The water cooling and construction of lava barriers definitely have had a marked effect on the character and course of the lava flows on Heimaey. From boreholes drilled into various parts of the lava field north of Eldfell, temperature measurements indicated that the lava cooled 50 to 100 times more rapidly in areas sprayed with seawater than in areas of self-cooling. The placement and measurement of movement of markers (from ground surveys and aerial photographs) on the lava field substantiate the effect of cooling on the speed of lava flow. It has been established clearly that the work on Heimaey represented the greatest effort ever attempted to control lava flows during the course of an eruption; the total estimated cost for the lava cooling operations (labor, equipment, transportation, fuel, and others) was $\$ 1.5$ million.

\section{Extraction of Heat From Cooling Lava Flows}

Scientists and engineers from the University of Iceland, residents of Heimaey, and an Icelandic engineering firm, Verkfraedistofa Gudmundar og Kristjăns, teamed up to create a district-heating system for the town of Vestmannaeyjar using the thermal energy from the cooling lava flows. Initial feasibility studies on the eastern part of the new lavas indicated that about 5 yards of scoria (tephra) lay on top of about 100 yards of new lava, all of which was resting on the former sea bottom. It was also determined that molten lava was slowly cooling inward from the top and bottom of new lavas, but that the thermal energy from this molten lava could be used to provide space heating to the town of Vestmannaeyjar.

By early 1974, heating experiments had proven successful, and the first house was connected to a

Vertical aerial thermograph taken on August 20,1973 , at $2233 \mathrm{hrs}$ UT of the island of Heimaey, Vestmannaeyjar, Iceland, showing the thermal emission from joints and fissures in the cooling lava flows (compare with the September 8, 1973, aerial photograph on $p$. 19) (courtesy of NASA). 


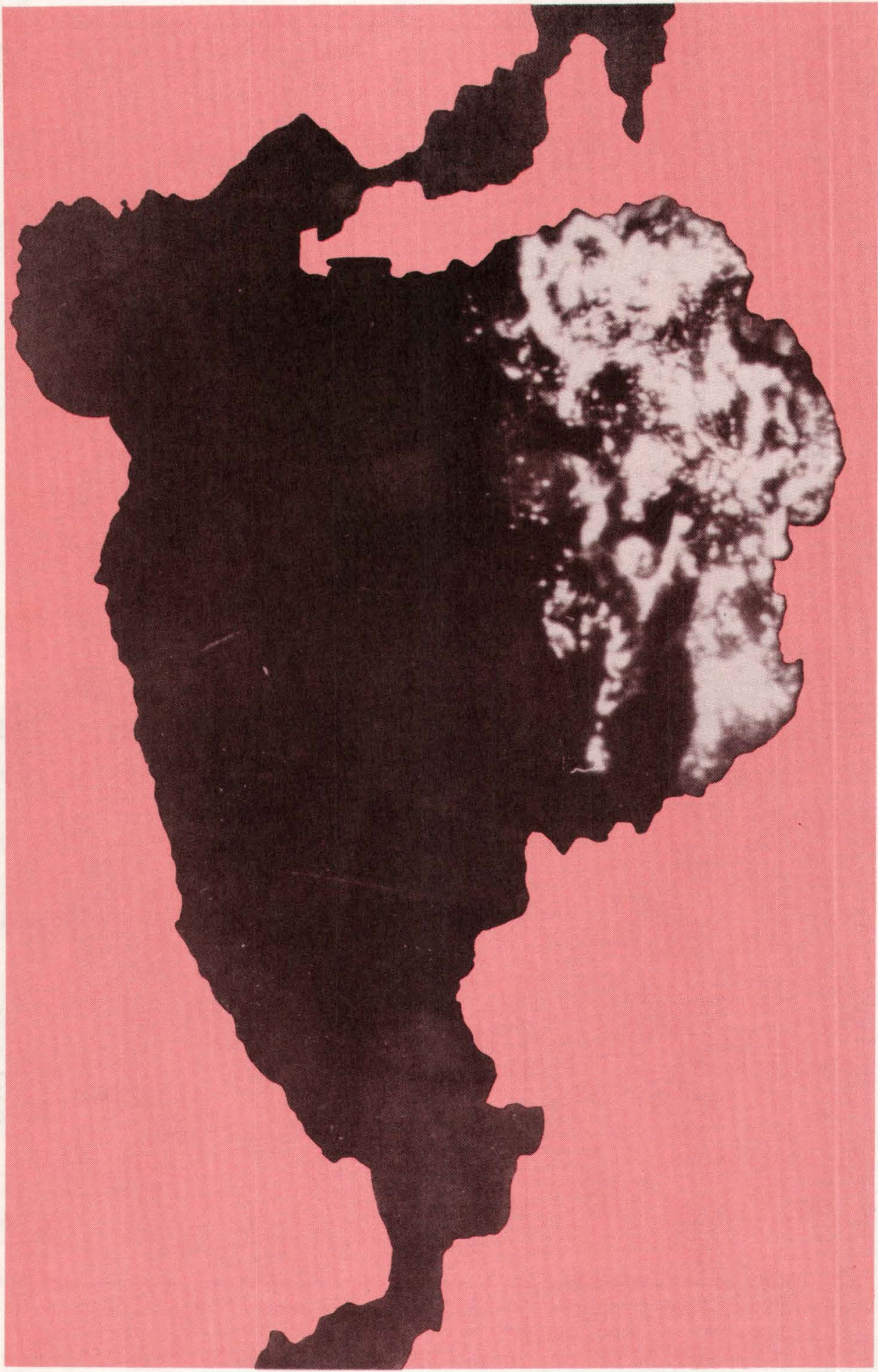




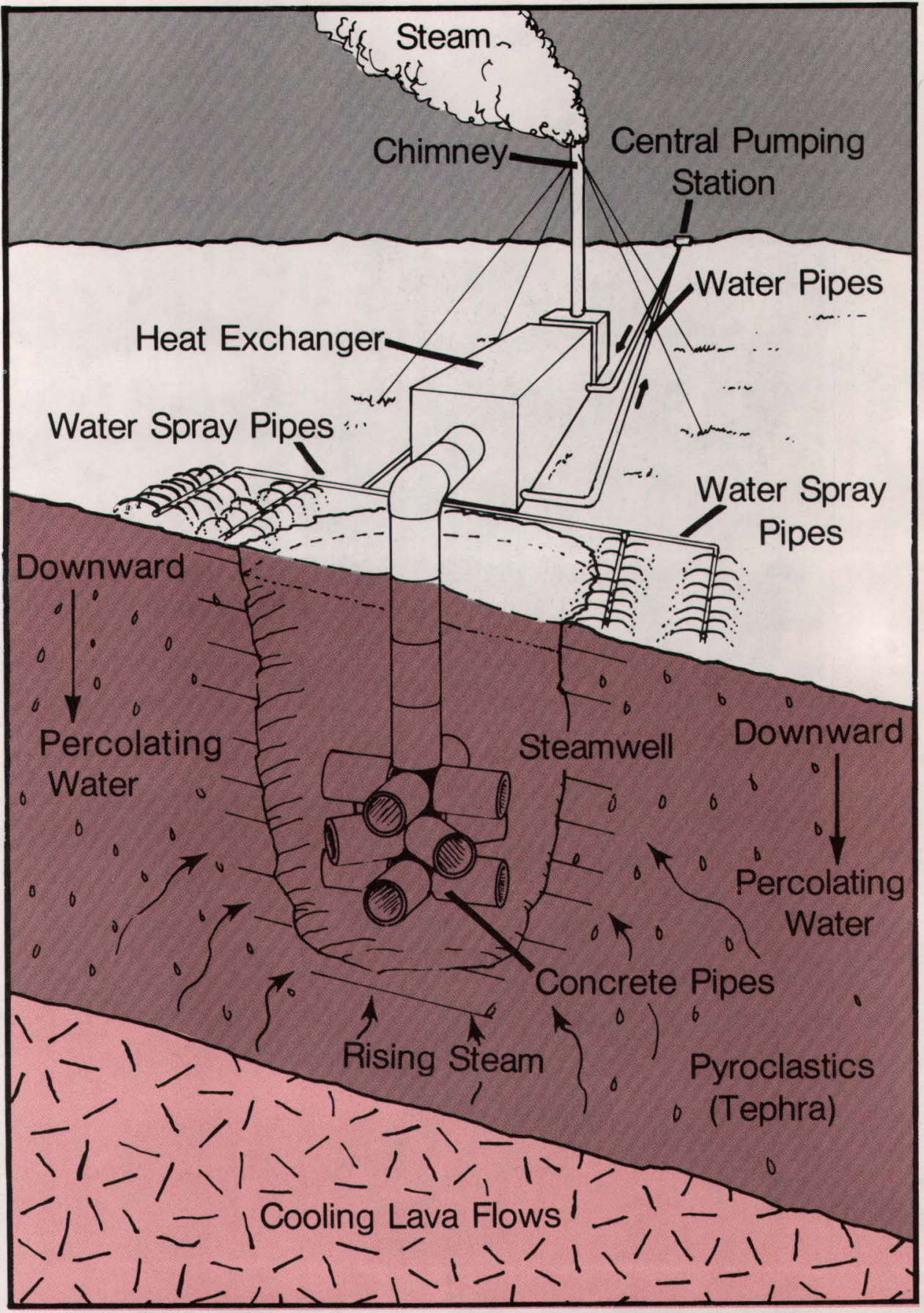

Cutaway schematic diagram of the subsurface emplacement of concrete pipes above the cooling lava and connection to the heat exchanger on the surface to provide a source of heat for a district-heating system for the town of Vestmannaeyjar. (Modified from Björnsson, 1980, by permission of the author and the publisher, Atlantica and Iceland Review). 


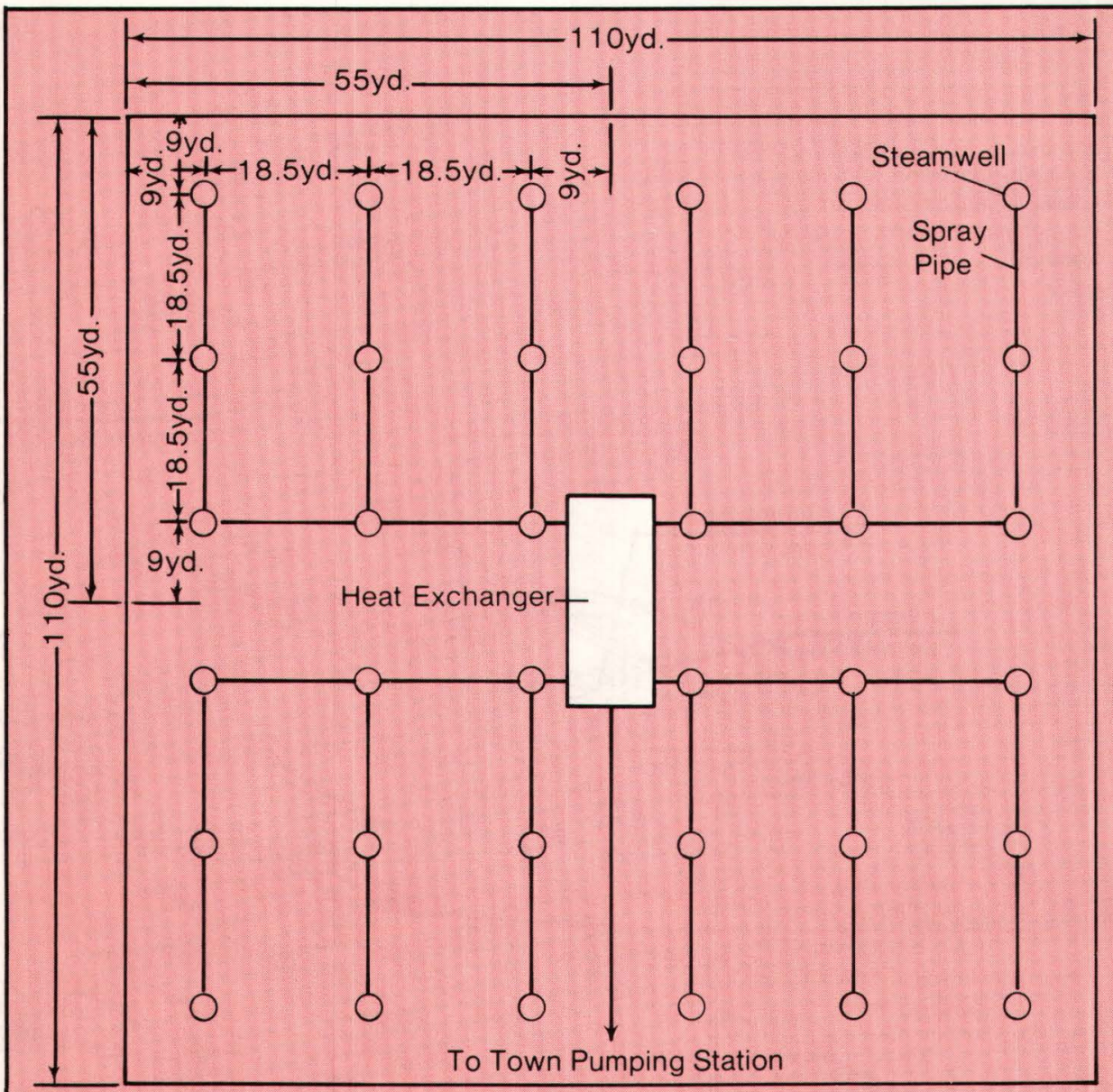

Schematic plan view of one of four square areas (110 yd $\times 110 \mathrm{yd})$ in lava field on Heimaey, where heat is extracted from cooling lavas at depth. Each one-fourth of this square area ( $55 \mathrm{yd} \times 55 \mathrm{yd}$ ) can generate 5 megawatts (MW) of hot water at peak load (or $2.5 \mathrm{MW}$ at normal load). (From information provided by Próf. Svienbjörn Björnsson, University of Iceland).

prototype system. Additional experiments were conducted during the next 5 years, and more houses and the hospital were hooked up to the heating system. By late 1979 , with the design for a heating system based on cooling lava experimentally proven, a major engineering effort got underway to develop 4 areas, each $110 \mathrm{yd} \times 110 \mathrm{yd}$ square, in the eastern part of the new lavas. Each area was designed so that the fixed facilities (pumping stations and heat exchangers) were centrally located. Each quarter section, 55 yd $\times 55$ yd square, during operation contains a matrix of nine steamwells spaced at $18.5 \mathrm{yd}$ intervals and is capable of producing 5 megawatts (MW) of peak power or $2.5 \mathrm{MW}$ at normal operation. The steamwells are constructed in the unconsolidated tephra deposits, and a series of short concrete pipes are laid horizontally, one on top of the other, in a 
Isometric diagram of layout of the $5 \mathrm{MW}$ piping system to and from the cooling lava field, heat exchangers, and to and from the town pumping system. (From information provided by Próf. Svienbjörn Björnsson, University of Iceland, and from the information booklet, "Fjarhitun Vestmanneyja-Upplysingar um Veituna," 20 March 1982, 5 p. (In (celandic)).

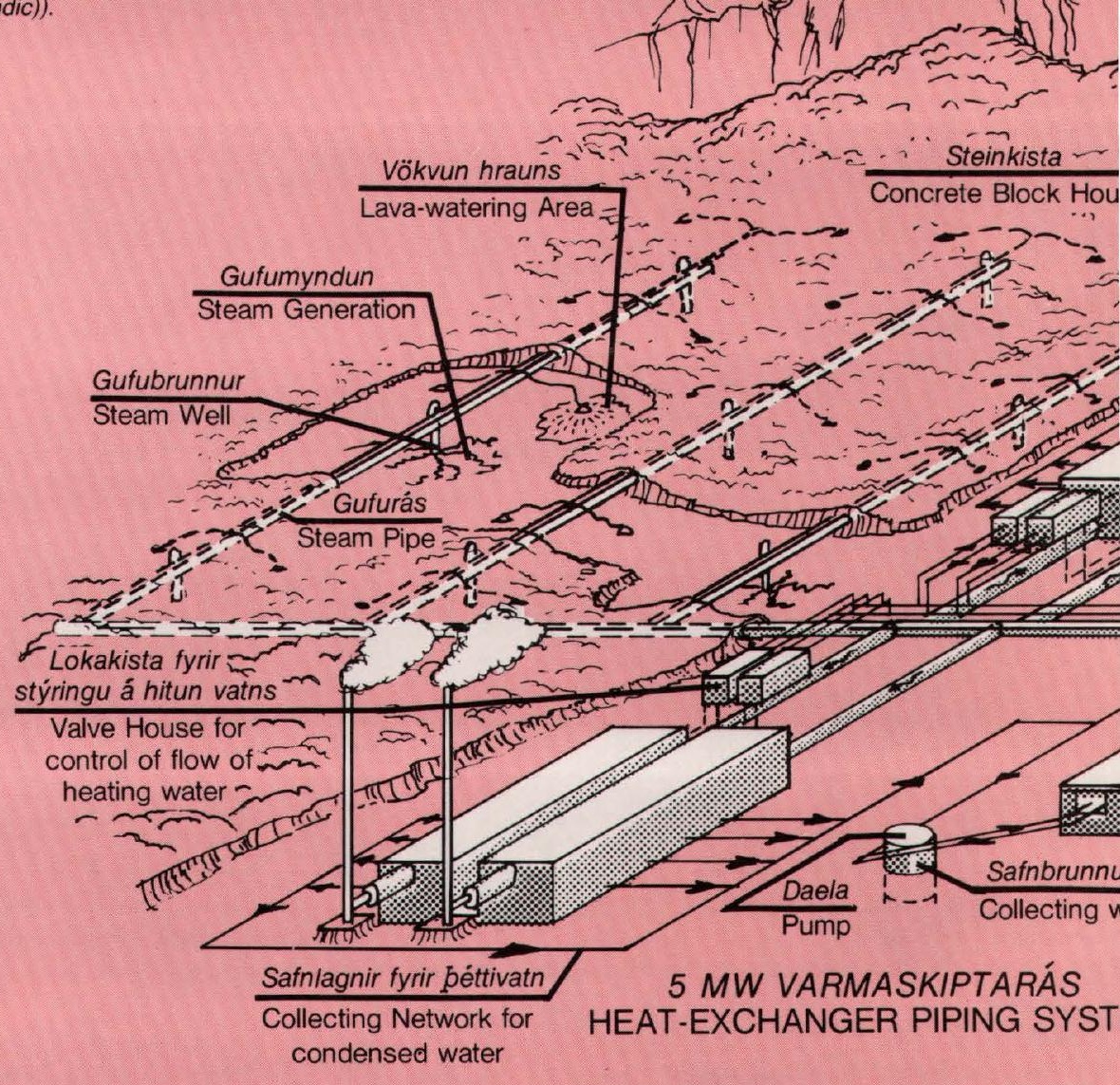

branching fashion to collect the steam. An overlying network of pipes sprays water onto the area surrounding the steamwells. The water percolates downward until it encounters the cooling lava where it is converted to steam. The steam rises vertically where it is collected by the steamwells and moves through pipes to the heat exchangers, which heat up water circulat- ing through the central heating system of the town. Water at a temperature of $176^{\circ} \mathrm{F}$ is supplied to the town pumping station; $95^{\circ} \mathrm{F}$ water is returned from the town pumping station.

By early 1982 , the district heating system had been connected to nearly every home on Heimaey. According to Dr. Sveinbjörn Björnsson, Professor of Geophysics 


\section{Conclusion}

Even after all the devastation and disruption of lives and livelihood, the volcanic eruption had some peripheral benefits. On the plus side, the lava and tephra added nearly a square mile to the preeruption area of Heimaey, increasing the island's size by about 20 percent. About 2 million cubic yards of tephra have been cleared away from the town and have been used to extend the runways on the island's only airfield and as landfill for the siting of 200 new homes. Even the remaining heat of the volcano has been tapped, an effort first begun in January 1974, only 1 year after the eruption began. The tongue of lava that almost blocked the harbor entrance has also been turned into an asset and is now acting as a breakwater, helping to protect the harbor from storms.

Another aspect of the recovery effort was the enormous cleanup and restoration effort funded by all Icelanders through a special surtax and by Iceland's foreign friends. Substantial economic help was provided by the government and private groups and organizations of the other Nordic countries. The Danish Government was the biggest benefactor, providing direct assistance of $\$ 1,488,000$. The U.S. Government provided $\$ 339,000$ in direct and indirect assistance. Even the tiny Faeroe Islands contributed $\$ 97,600$. The value of assistance from all nations was about $\$ 2,100,000$, with an additional $\$ 380,000$ provided by international organizations and private groups, such as the American-
Scandinavian Foundation. By the summer of 1974 , about 2,600 residents, or about one-half of the population, had returned and plans had been developed for the construction of an additional 450 new homes. By March 1975 the population had grown to 4,300 people, or 80 percent of the preeruption population. By December 1, 1982, the population of Vestmannaeyjar had reached 4,657. Vestmannaeyjar once again has become a vigorous fishing community, a laboratory for geologists, a major tourist attraction, and a testimony to the perseverance and courage of the islanders to turn, with the help of other Icelanders and foreign friends, a seemingly hopeless situation into a bright future.

The success of the islanders in their battle with the volcano has prompted other communities faced with volcanic hazards to look to the lessons learned on Heimaey. The worldwide interest has contributed to making Eldfell one of the best known volcanic eruptions in the world. Scientists in Iceland and around the world will be studying the photographs, aerial thermographs, and rock samples for years to come, looking for clues that will contribute to an understanding of the nature of volcanoes, as well as for methods to mitigate the destructive effects of future eruptions whether they be in Iceland, in the United States, or in any other inhabited volcanic region of the world. 


\section{Selected Readings}

Björnsson, Sveinbjörn, 1980, Natural heat saves millions of barrels of oil: Unique procedures developed by Icelanders-they even tap hot lava: Atlantica and Iceland Review, v. 18, no. 1, p. 28-37.

Einarsson, Thorleifur, 1974, The Heimaey eruption in words and pictures: Heimskringla, Reykjavík, $56 \mathrm{p}$.

Grove, Noel, 1973, Volcano overwhelms an Icelandic village: National Geographic Magazine, v. 144 , no. 1 , p. $40-67$.

Gunnarsson, Árni, 1973, Volcano: Ordeal by fire in Iceland's Vestmann Islands: Iceland Review Book Series, Iceland Review, Reykjavík, $96 \mathrm{p}$.

1974 , Life returns to the Westman Islands yet the marks of the volcanic eruption are here to stay: Atlantica and Iceland Review, v. 12, no. 1-2, p. 33-40.

Hamar, H. J., 1976, People are back to the Westman Islands-but life will never be quite the same: Atlantica and Iceland Review, v. 14, no. 4, p. 14-20.

Jonsson, V. K., and Matthíasson, Matthías, 1974, Lava cooling on Heimaey-methods and procedures: Tímarit VFI, v. 59, no. 5, p. 70-81, and p. 83. (In Icelandic)

Sigurgeirsson, Thorbjörn, 1974, Lava cooling: Tíminn, 19 January 1974, Reykjavík, p. 8-9 and p. 13. (In Icelandic)

Thorarinsson, Sigurdur, 1964, Surtsey-the new island in the North Atlantic: Almenna Bókafélagid, Reykjavík, 110 p. (In Icelandic) (Also reprinted in English by the Viking Press, New York, in 1967)

1977, The eruption fissures of the 1973 Heimaey eruption: Náttúrufraedingurinn, v. 47, no. 1 , p. 1-7. (In Icelandic)

Thorarinsson, Sigurdur, Steinthórsson, Sigurdur, Einarsson, Thorleifur, Kristmannsdóttir, Hrefna, and Oskarsson, Níels, 1973, The eruption on Heimaey, Iceland: Nature, v. 241, no. 5389,

p. $372-375$.

\section{Movies About the 1973 Eruption on Heimaey}

Fire on Heimaey (Eldur i Heimaey), VóK Film, Reykjavík, Iceland.

Days of Destruction, Iceland Film Distributors, Kvik sf. kvikmyndagerd, Reykjavík, Iceland.

The Heimaey Eruption: Iceland 1973, University of Waterloo, Department of Man-Environment Studies, Waterloo, Ontario, Canada.

Volcanoes, Exploring the Restless Earth, Encyclopedia Britannica, Educational Corporation, Chicago, Illinois.

Season of Fire, MacMillan Films, Inc., Mount Vernon, New York.

Volcano, IMAX Systems Corporation, Toronto, Ontario, Canada.

This publication is one of a series of general interest publications prepared by the U.S. Geological Survey to provide information about the earth sciences, natural resources, and the environment. To obtain a catalog of additional titles in the series "Popular Publications of the U.S. Geological Survey," write:

Eastern Distribution Branch or Western Distribution Branch

U.S. Geological Survey

604 South Pickett Street

Alexandria, VA 22304

U.S. Geological Survey

Box 25286, Federal Center

Denver, CO 80225 
The measurements used in this publication can be converted to metric equivalents by using the appropriate entries from the following table:

\section{Approximate Conversions}

\begin{tabular}{|c|c|c|c|}
\hline & To convert & to & $\begin{array}{c}\text { Multiply } \\
\text { by }\end{array}$ \\
\hline Length & $\begin{array}{l}\text { inch }(\mathrm{in}) \\
\text { foot }(\mathrm{ft}) \\
\text { yard }(\mathrm{yd}) \\
\text { rod } \\
\text { statute mile (mi) } \\
\text { nautical mile }\end{array}$ & $\begin{array}{l}\text { centimeter }(\mathrm{cm}) \\
\mathrm{cm} \\
\text { meter }(\mathrm{m}) \\
\mathrm{m} \\
\text { kilometer }(\mathrm{km}) \\
\mathrm{km}\end{array}$ & $\begin{array}{c}2.5 \\
30.0 \\
0.91 \\
5.0 \\
1.61 \\
1.85\end{array}$ \\
\hline Area & $\begin{array}{l}\text { square inch }\left(\mathrm{in}^{2}\right) \\
\text { square foot }\left(\mathrm{ft}^{2}\right) \\
\text { acre }\left(43,560 \mathrm{ft}^{2}\right) \\
\text { square mile }\end{array}$ & $\begin{array}{l}\mathrm{cm}^{2} \\
\mathrm{~m}^{2} \\
\text { hectare (ha) } \\
\mathrm{km}^{2}\end{array}$ & $\begin{array}{l}6.45 \\
0.093 \\
0.405 \\
2.6\end{array}$ \\
\hline Volume & $\begin{array}{l}\text { US: } \\
\text { quart (qt) } \\
\text { gallon (gal) } \\
\text { barrel ( } 42 \text { gal) } \\
\text { cubic foot } \\
\text { cubic yard }\end{array}$ & $\begin{array}{l}\text { liter (L) } \\
L \\
L \\
m^{3} \\
m^{3}\end{array}$ & $\begin{array}{c}0.95 \\
3.8 \\
160.0 \\
0.028 \\
0.76\end{array}$ \\
\hline Mass & $\begin{array}{l}\text { ounce (oz) } \\
\text { pound (Ib av) } \\
\text { short ton }(2,000 \mathrm{lb})\end{array}$ & $\begin{array}{l}\text { gram }(\mathrm{g}) \\
\text { kilogram }(\mathrm{kg}) \\
\text { metric ton }(\mathrm{t})\end{array}$ & $\begin{array}{l}28.0 \\
0.454 \\
0.907\end{array}$ \\
\hline
\end{tabular}

The approximate conversions are derived from the following factors:

$$
\begin{aligned}
& 1 \text { inch }=2.54 \text { (exact) centimeters } \\
& 1 \text { pound }=0.4535924 \text { kilograms }
\end{aligned}
$$




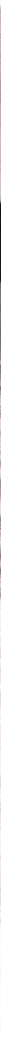

Oblique aerial view in early March 1973 of Heimaey, Vestmannaeyjar, Iceland: Steam rises from lava-cooling operations on land and from lava entering the sea (photo by Gudmundur Sigfússon. Courtesy of Sólarfilma). 
As the Nation's principal conservation agency, the Department of the Interior has responsibility for most of our nationally owned public lands and natural resources. This includes fostering the wisest use of our land and water resources, protecting our fish and wildlife,

preserving the environmental and cultural values of our national parks and historical places, and providing for the enjoyment of life through outdoor recreation. The Department assesses our energy and mineral resources and works to assure that their development is in the best interests of all our people. The Department also has a major responsibility for American Indian reservation communities and for people who live in Island Territories under U.S. administration. 